\title{
Higher Education on Building Energy and Sustainability in North Dakota
}

\author{
Huojun Yang $^{1}$, Malini Srivastava ${ }^{2}$ and Yanmei Xie ${ }^{1}$ \\ 1. Department of Construction Management and Engineering, North Dakota State University, Fargo, ND 58108, USA \\ 2. Department of Architecture and Landscape Architecture, North Dakota State University, Fargo, ND 58108, USA
}

Received: June 14, 2016 / Accepted: June 23, 2016 / Published: September 30, 2016.

\begin{abstract}
Located in the cold and very cold semiarid steppe climate zone, North Dakota boasts not only long cold winters but also hot summers, which significantly increases the energy consumption of buildings. In fact, North Dakota has the highest energy consumption per capita in residential buildings (101 MM Btu in 2013), and its energy consumption per capita in commercial buildings ranks the second (118 MM Btu in 2013) in the nation. When humans spend a long time indoors to escape the inclement weather, their health will be more susceptible to the indoor environment. In addition, North Dakota has the 3rd least number of green buildings certified by LEED (Leadership in Energy and Environmental Design) in the nation. This paper aims to investigate the status quo of buildings with respect to energy, health and sustainability in North Dakota, and attempts to propose strategies regarding research and higher education to rectify the current issues. These strategies include but not limited to forming the architectural engineering program, a comprehensive and interdisciplinary program in buildings.
\end{abstract}

Key words: Higher education, building, energy, sustainability, green building, architectural engineering, North Dakota.

\section{Introduction}

Buildings in the US consume $41 \%$ of primary energy, $72 \%$ of electricity, and $36 \%$ of natural gas, and the building sector is the biggest contributor to the greenhouse gas emissions. While energy is important to both budgets and the environment, health and comfort are more critical to building occupants. IAQ (indoor air quality) is a vital term indicating if a building environment is healthy and comfortable to occupants. The WHO (World Health Organization) estimated that up to $30 \%$ of new or remodeled commercial buildings may have unusually high rates of health and comfort complaints from occupants that may potentially be related to IAQ [1]. Today, $14 \%$ of healthcare costs are also driven by conditions related to IAQ [1]. Besides IAQ, there are other physical and psychological factors of life indoors that will affect the

Corresponding author: Huojun Yang, Ph.D., assistant professor, research fields: architectural engineering, building energy systems, and built environment. comfort of occupants in buildings such as lighting, visual quality, acoustics, and thermal comfort.

Commonly, each building's performance aspect regarding energy efficiency, health, and sustainability is interrelated and affected by one another. In many cases, the improvement of one factor in a building will sacrifice the performance of another. For example, the current practice of a tighter and more energy efficient construction [1], where the exchange of indoor and outdoor air is significantly reduced for energy savings, may have the IAQ issue because the unwanted contaminants will be trapped in the tight environment. However, there are few studies to cover comprehensively these factors such as climate, building design, construction, building equipment, operation and maintenance, occupant behavior, IAQ, lighting, visual quality, acoustics, and thermal conditions, and their impacts on buildings' health, energy efficiency and sustainability. There is also lack of investigation on how these factors interact with each other to impact the 
composite performance regarding buildings' health, energy efficiency, and sustainability. In addition, with respect to buildings' individual performance of health, energy efficiency, and sustainability, further research is still needed to find an optimal solution, such as how to fast detect and identify various indoor bioaerosols on site. To rectify this situation, more professional experts are needed to be created by higher education institutions to effectively solve the current issues and continuously provide innovations with respect to the healthy, energy effiicent and sustainable buildings.

However, North Dakota has already lagged far behind other states in the local region and in the nation with respect to building-related research and higher education, and its severe situations of existing buildings and its recent fast development make the higher education on buildings more important and urgent. Thus, this paper firstly analyzes the status quo of buildings in North Dakota with respect to energy, health and sustainability, investigates the current situation of higher eduction on buildings in North Dakota, and proposes a strategy to handle lack of higher education programs so that more local professional experts are created in the field of buildings to rectify the current issues of buildings and to continually support the healthy and sustainable buildings with high energy efficiency across their lifetime.

\section{Status Quo of Buildings in North Dakota}

Most existing buildings in North Dakota do not meet the requirements of mainstream building energy codes, e.g., IECC (International Energy Conservation Code), International Building Code, and ANSI/ASHRAE Standard 90.1 "Energy Standard for Buildings Except Low-Rise Residential Buildings" and 90.2 "Energy-Efficient Design of Low-Rise Residential Buildings”. Furthermore, North Dakota has not adopted a statewide building energy code, though some of its local counties/jurisdictions have recently undertaken or are in the process of adopting building energy codes. The city of Fargo adopted the 2009 IECC on June 14, 2010, but did not enforce any energy conservation code prior to 2010. The entire status quo of buildings in North Dakota can be conjured up through the following facts from buildings at North Dakota State University: Most of the buildings on campus do not have energy monitoring of any kind like water, steam or electrical meters. Without metering, it makes it tough to evaluate energy systems. Most of the buildings have no automatic control systems, and even the pneumatic control systems currently installed only allow setpoints to be reset manually. Other issues also include building air leakage, poor insulation, low efficient lighting, constant speed motors, low efficiency motors, and imbalanced HVAC air flow systems.

The energy consumption of buildings in North Dakota has been significantly increased due to both the long very cold winters and hot summers. In fact, North Dakota has the highest energy expenditure per capita (\$10,540 in 2013), and its energy consumption per capita ranks 4th in the nation according to the US EIA (Energy Information Administration). Furthermore, in terms of building sector, as one of the fives states spanned in the Northern Great Plains, with their building energy consumptions per capita of top 6 (160-220 MM Btu in 2013) in the nation, North Dakota has not only the highest building energy consumption per capita in its local region, but its residential building energy consumption per capita (101 MM Btu in 2013) and its commercial building one (118 MM Btu in 2013) respectively rank 1st and 2nd in the nation.

Furthermore, the long, cold, windy, and snowy winters make the residents in North Dakota spend more time in buildings than the average American (EPA estimated that the average American spends approximately $90 \%$ of their time indoors). Thus, building energy consumption is increasingly affected by people's behavior and their health will be more dependent on indoor environment quality. Also, buildings in North Dakota are subject to moisture issues due to flooding and snow, so more moisture control techniques are required to avoid the insulation 
degradation and the growth of bacteria/molds. In addition, North Dakota has the third least number of green buildings certified by LEED (Leadership in Energy and Environmental Design) in the nation. What is more important, these issues are compounded by the building boom that has swept the state-it's estimated that 74,000 new residents moved to North Dakota between 2010 and 2014-because there exists no information about how buildings in North Dakota impact energy consumption or human health, and there is no statewide building code so far in North Dakota to guarantee these new buildings are healthy, energy efficient, and sustainable.

\section{Current Situation of Higher Education on Buildings in North Dakota}

With respect to building-related higher education and research, North Dakota has already lagged far behind other states in the nation. First, there is no comprehensive academic program or research center in North Dakota to focus on various aspects of buildings although some specific topics with buildings are studied in few scattered departments. Second, no specific program funds the research with buildings' energy efficiency, health, and indoor environment in the state. Third, very few case studies with buildings have been conducted in North Dakota. For example, North Dakota has been excluded in a recent study regarding concentrations of airborne culturable bacteria in 100 US office buildings [2].

As shown in Fig. 1, the comprehensive curriculum areas related with buildings typically include: architecture and building design, construction/ construction management, building structures, building mechanical systems, building electrical and lighting systems, acoustics, fire protection, indoor environment, and sustainability. The academic catalogs [3-7] were investigated to study the building-related courses for the major six higher education institutions in North Dakota, including BSC (Bismarck State College), CCCC (Cankdeska Cikana Community College),
NDSCS (North Dakota State College of Science), NDSU (North Dakota State University), TMCC (Turtle Mountain Community College), and UND (University of North Dakota). Table 1 shows the statistics of building-related curriculum areas offered by the six post-secondary institutions. From Table 1, no institutions provide courses regarding fire protection, acoustics, or building sustainability, and only TMCC offers one basic course with respect to indoor environment, "HVAC114: Indoor air quality solutions". All institutions list courses for building mechanical systems, and they also have the program of "construction/construction management" with exception to UND. Most of them offer courses related with building electrical/lighting systems (with exception to BSC and UND), and half of them (BSC, NDSCS and NDSU) provide courses architecture/building design. Only two institutions have the professional courses regarding building structure.

In general, there is an imbalance among these curriculum areas related with buildings. All institutions offer courses about building mechanical systems with a specific focus for each institution, but no one provides courses in the building areas of fire protection, acoustics, and sustainability. In terms of indoor environment, only one introductory or similar course is offered by TMCC. Most institutions offer courses in the fields of construction/construction management and building electrical/lighting systems. Courses in architecture/building design and building structure are more or less provided by several institutions.

In terms of program development, both architecture/ building design and construction/construction management have an independent program in a couple of institutions. Building structure and building mechanical systems have been listed as an area emphasis in the civil engineering program and the construction/construction management program respectively, in few institutions. For other areas related with buildings, there is no specific field emphasis or program, and only some courses are oddly offered. 


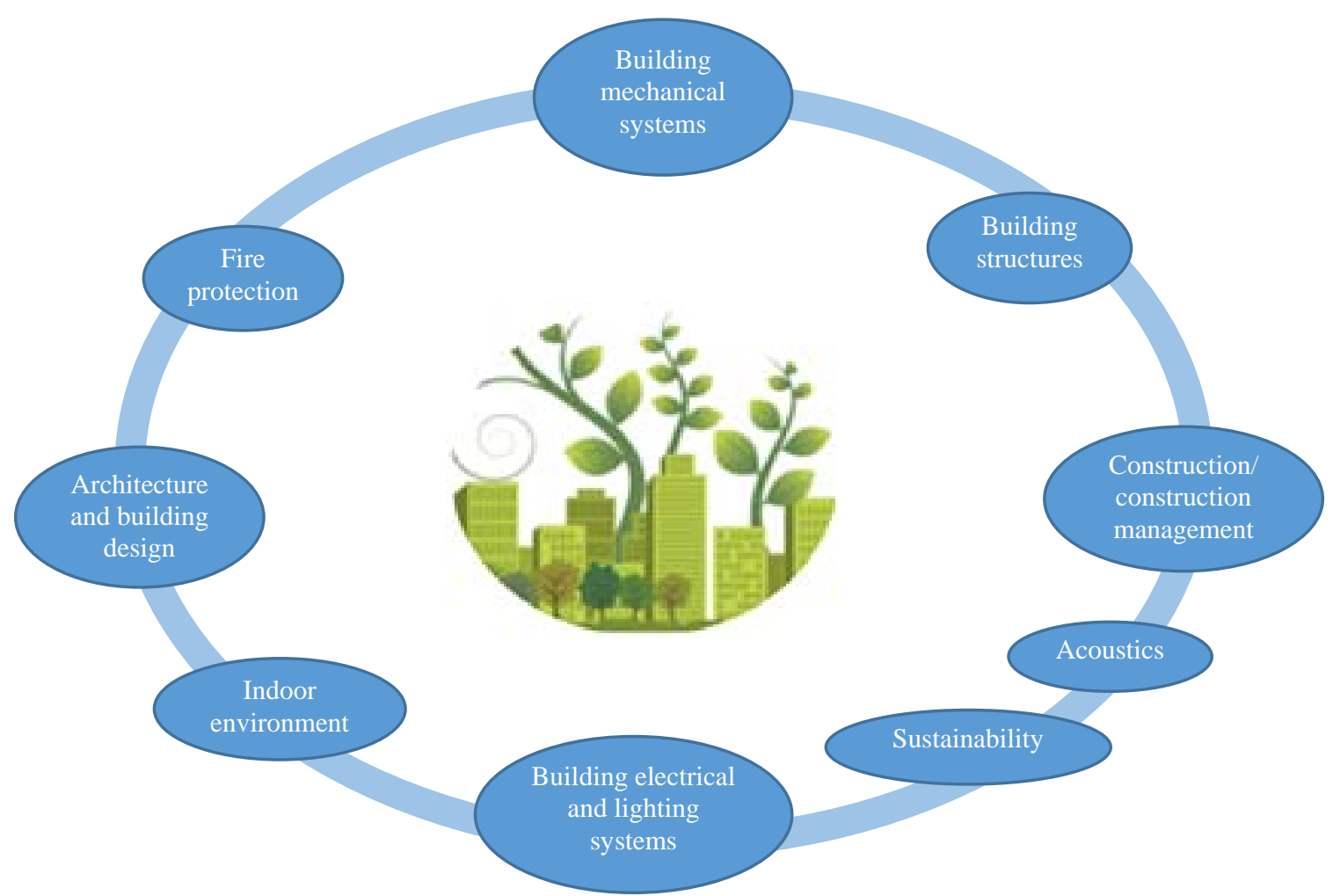

Fig. 1 Comprehensive curriculum areas related with buildings. A comprehensive program related with buildings offers curriculum areas, including architecture and building design, structures, construction, mechanical systems, electrical and lighting systems, indoor environment, acoustics, fire protection, and sustainability.

Table 1 Statistics of building-related curriculum areas offered by postsecondary institutions in North Dakota.

\begin{tabular}{|c|c|c|c|c|c|c|c|c|c|}
\hline $\begin{array}{l}\text { Curriculum } \\
\text { areas }\end{array}$ & $\begin{array}{l}\text { Architecture } \\
\text { \& building } \\
\text { design }\end{array}$ & $\begin{array}{l}\text { Construction } \\
\text { /construction } \\
\text { management }\end{array}$ & $\begin{array}{l}\text { Building } \\
\text { structure }\end{array}$ & $\begin{array}{l}\text { Building } \\
\text { mechanical } \\
\text { system }\end{array}$ & $\begin{array}{l}\text { Building } \\
\text { electrical } \\
\text { \& lighting } \\
\text { system } \\
\end{array}$ & $\begin{array}{l}\text { Indoor } \\
\text { environment }\end{array}$ & $\begin{array}{l}\text { Fire } \\
\text { protection }\end{array}$ & Acoustics & Sustainability \\
\hline \multirow{6}{*}{$\begin{array}{l}\text { Post- } \\
\text { secondary } \\
\text { institutions }\end{array}$} & BSC & BSC & NDSCS & BSC & CCCC & TMCC & & & \\
\hline & NDSCS & CССC & NDSU & CССC & NDSCS & & & & \\
\hline & \multirow[t]{4}{*}{ NDSU } & NDSCS & & NDSCS & NDSU & & & & \\
\hline & & NDSU & & NDSU & TMCC & & & & \\
\hline & & TMCC & & TMCC & & & & & \\
\hline & & & & UND & & & & & \\
\hline Total & 3 & 5 & 2 & 6 & 4 & 1 & 0 & 0 & 0 \\
\hline
\end{tabular}

In terms of strength of individual institution with respect to buildings, both NDSU and NDSCS have more comprehensive curriculum areas than others, and TMCC is the only one with the curriculum area of indoor environment. For the depth of course, only NDSU and UND provide courses for bachelor degree, and others for only associate degree, pre-engineering, or certificate. In addition, so far no graduate courses are offered and graduate programs exist on buildings in North Dakota.

\section{Results and Discussions}

With the fast economic development, population increase, and housing boom in North Dakota, a more comprehensive academic program or curriculum areas regarding buildings, e.g., AE (architectural engineering) 
program, needs to be developed, so that the local professionals with a more overall knowledge of buildings can be trained and provided to support the state's continuous development through its own higher education institutions. Architectural engineers design/redesign the systems inside/throughout the building that make it functional, comfortable, and healthy. The new AE program can be started from scratch, or be developed based on an existing building-related program, e.g., construction/construction management or civil engineering. The integration of $\mathrm{AE}$ with other existing programs will facilitate its development.

On the other hand, the job market related with buildings is developing in North Dakota, and most positions are still focusing on the lower level profession requirements that just make the buildings functional. This market demand can be satisfied in the short term by the current post-secondary education in North Dakota. However, the recent population boom and housing boom in North Dakota will make the advanced properties of buildings more urgent, including but not limited to the energy efficiency, sustainability, comfort and health. To achieve these buildings' goals, the current curriculums originally designed for associate degrees, pre-engineering, certificate, and even the bachelor's degrees are insufficient for the local professionals to handle the never-ending upgraded engineering and research issues related with buildings. Therefore, the more advanced graduate courses and graduate programs should be developed in North Dakota to fill this academic gap so that local professionals from these programs can provide technologies and innovations that make buildings more energy efficient, more comfortable, more sustainable, and healthier.

\section{Conclusions}

This paper compared the performance of buildings in North Dakota with that in other states, and investigated the status quo and development of buildings in North Dakota and the state's current situation of higher education on buildings. The current postsecondary programs on buildings in North Dakota far lag its status quo and recent development of buildings. To rectify this situation, a more comprehensive program regarding buildings, e.g., architectural engineering, and more advanced graduate programs and curriculums throughout the life cycle of buildings are proposed so that more local professional experts work on the functional, energy efficient, comfortable, healthy, and sustainalble buildings across their lifetime.

\section{References}

[1] Bloech, H. 2014. "Pioneering Indoor Air Quality Certification for Buildings.” UL. Accessed Jan. 20, 2016. http://newscience.ul.com/wpcontent/uploads/2014/11/UL _NS_IAQ_PioneeringIndoorAirQuialityCertificationFor Buildings_Article.pdf.

[2] Tsai, F. C., and Macher, J. M. 2005. "Concentrations of Airborne Culturable Bacteria in 100 Large US Office Buildings from the BASE Study.” Indoor Air 15: 71-81.

[3] Academic Catalog of North Dakota State College of Science. 2015-2016. Accessed Jan. 20, 2016. https://www.ndscs.edu/academics/things-to-know-acade mics/course-schedules-catalogs/.

[4] Academic Catalog of Bismark State College. 2015-2016. Accessed Jan. 20, 2016. http://www.bismarckstate.edu/uploads/resources/6136/ac ademic-catalog-2015-2016-reg-001-0315.pdf/.

[5] Academic Catalog of Cankdeska Cikana Community College. 2014-2015. Accessed Jan. 20, 2016. http://www.littlehoop.edu/content/images/Documents/Ca nkdeska\%20Cikana\%20College\%20Catalog\%202014-20 15.pdf.

[6] Academic Catalog of Turtle Mountain Community College. 2015-2016. Accessed Jan. 20, 2016. http://www.tm.edu/wp-content/uploads/2015/08/2015-16Catalog-Revised-8-7-15-FINAL-FINAL.pdf/.

[7] Academic Catalog of University of North Dakota. 2015-2016. Accessed Jan. 20, 2016. http://und-public.courseleaf.com/pdf/2015-2016.pdf/. 